\title{
Correction to: Stability Indicating RP-HPLC Method Development and Validation for Simultaneous Quantification of 15 Organic Impurities of Olmesartan Medoxomil, Amlodipine and Hydrochlorothiazide in Combined Dosage Form
}

Pritesh R. Desai ${ }^{1,2} \cdot$ Priti J. Mehta ${ }^{2}$ - Avani B. Chokshi ${ }^{3}$

Published online: 22 July 2019

๑) Springer-Verlag GmbH Germany, part of Springer Nature 2019

\section{Correction to: Chromatographia (2019) 82:819-833 https://doi.org/10.1007/s10337-019-03718-9}

The authors would like to call the reader's attention to the following change in the corresponding authorship to Priti J. Mehta and Pritesh R. Desai's affiliation:

Pritesh R. Desai ${ }^{1,2}$. Priti J. Mehta ${ }^{2} *$ Avani B. Chokshi ${ }^{3}$

*drpritimehta@nirmauni.ac.in

1 Department of Analytical Research, Zydus Cadila Healthcare Limited, Moraiya, Ahmedabad, Gujarat 382213, India
2 Institute of Pharmacy, Nirma University, Ahmedabad, Gujarat 382481, India

3 Ramanbhai Patel College of Pharmacy, CHARUSAT, Changa, Gujarat 388421, India

Publisher's Note Springer Nature remains neutral with regard to jurisdictional claims in published maps and institutional affiliations.

Pritesh R. Desai-Research scholar from Institute of Pharmacy,

Nirma University, Ahmedabad, Gujarat, 382481 India.

The original article can be found online at https://doi.org/10.1007/ s10337-019-03718-9.

Priti J. Mehta

drpritimehta@nirmauni.ac.in

1 Department of Analytical Research, Zydus Cadila

Healthcare Limited, Moraiya, Ahmedabad, Gujarat 382213, India

2 Institute of Phamacy, Nirma University, Ahmedabad, Gujarat 382481, India

3 Ramanbhai Patel College of Pharmacy, CHARUSAT, Changa, Gujarat 388421, India 